\title{
EFEKTIVITAS MODEL OPEN INQUIRY TERHADAP KETERAMPILAN PROSES SAINS PADA MATERI EKOSISTEM
}

\section{EFFECTIVITY OF OPEN INQUIRY MODELS ON SCIENCE PROCESS SKILS IN ECOSYSTEM MATERIAL}

\author{
Eva Yuliana ${ }^{*}$ \\ ${ }^{1}$ Dosen Pendidikan Pendidikan Biologi, Fakultas Keguruan dan Ilmu Pendidikan, \\ Universitas Wiralodara Indramayu, Indonesia \\ *Email: evayuliana@unwir.ac.id
}

Diterima: 23 Juni 2020. Disetujui: 28 Juli 2020. Dipublikasikan: 21 Agustus 2020

\begin{abstract}
Abstrak: Tujuan penelitian ini untukmengetahui efektivitas model open inquiry terhadap keterampilan proses sains pada materi ekosistem di MAN 1 Indramayu. Jenis penelitian yang digunakan adalah metode kuantitatif dengan desain penelitian Quasi Eksperimen, menggunakan statistik parametrik dengan populasi dalam penelitian ini adalah seluruh siswa kelas X MAN 1 Indramayu yang berjumlah 185 siswadengan sempel dua kelas yaitu kelas X MIA 1 berjumlah 25 siswadan X MIA 2 berjumlah 20 siswa dengan teknik penarikan sampel cluster random sampling. Instrumen yang digunakan adalah lima butir soal uraian. Hasil pengolahan dan analisis data keterampilan proses sains diperoleh hasil uji hipotesis sebagai berikut: $t_{\text {hitung }}=6,0215$ dan $t_{\text {tabel }}=1,671$. Karena $T_{\text {hitung }}>t_{\text {tabel, }}$, maka dapat disimpulkan bahwa Ho ditolak, artinya model open inquiry efektif terhadap keterampilan proses sains siswa pada materi ekosistem.
\end{abstract}

Kata kunci : Model open Inquiry, Keterampilan Proses Sains, Ekosistem

\begin{abstract}
The purpose of this study was to determine the effectiveness of open inquiry models on science process skills in ecosystem material at MAN 1 Indramayu. The type of research was quantitative research, the design that used in this study was Quasi Experimental that use parametric statistics. The population in this study was all students of class X MAN 1 Indramayu which amounted to 185 students. They were in both class X MIA 1 totaling 25 students and X MIA 2 totaling 20 students with cluster random sampling technique. The instruments that used were five item description questions. Based on the results of processing and data analysis of science process skills obtained the results of hypothesis testing as follows: $t$ count $=6.0215$ and $t$ table $=1.671$. Because tcount $>$ ttabel, it could be concluded that Ho was rejected, meaning that the open inquiry model was effective toward the science skills' process of students in the ecosystem material.
\end{abstract}

Keywords : Open Inquiry Model, Science Process Skills, Ecosystem

\section{PENDAHULUAN}

Tuntutan kurikulum di Indonesia menekankan penerapan pendekatan ilmiah atau scientific approach pada proses pembelajaran [1] komponen-komponen penting dalam mengajar menggunakan pendekatan saintifik diantaranya adalah guru harus menyajikan pembelajaran yang dapat meningkatkan rasa keingintahuan, meningkatkan keterampilan mengamati, melakukan analisis dan berkomunikasi [2].

Kurikulum 2013 yang diterapkan mengedepankan keterampilan proses dimana sebuah pembelajaran harus sesuai dengan permasalahan yang ada di lingkungan sekitar, sehingga seswa selain memiliki pengetahuan dan keterampilan dalam memecahkan masalah, diharapkan juga mampu menguasai keterampilan lain yaitu keterampilan proses sains dapat berkembang serta mendapatkan pengalaman langsung dari proses belajarnya.
Pembelajaran Biologi yang termasuk dalam bagian Ilmu Pengetahuan Alam yang berkaitan dengan cara mencari tahu di alam yang sesungguhnya, bukan hanya kumpulan fakta, konsep, dan prinsip namun lebih ditekankan pada proses penemuan atau keterampilan proses yang dimiliki siswa sehingga tujuan pembelajaran dapat tercapai dengan baik. Namun pada kenyataannya di lapangan masih banyak pembelajaran yang menggunakan berbagai cara-cara pengajaran yang konvensional dan menekankan pada konsep semata yang tetap menjadikan guru sebagai sumber utama dalam proses pembelajaran atau teacher-centered

Pembelajaran biologi secaram umum guru masih mengajarkan fakta dan konsep melalui metode ceramah. Hal ini dilakukan karena terdesak waktu untuk mengejar pencapaian kurikulum. Akibatnya, para siswa memiliki banyak pengetahuan, tetapi tidak dilatih menemukan pengetahuan dan konsep serta sulit untuk mengembangkan pengetahuan dan kurang maksimalnya pengembangan Keterampilan Proses 
Sains siswa. Permendikbud No.81A Tahun 2013 lampiran IV, proses pembelajaran terdiri atas lima pengalaman belajar yaitu: mengamati, menanya, mengumpulkan informasi, mengasosiasi, dan mengkomunikasikan. Lebih lanjut disebutkan bahwa penemuan ilmu pengetahuan tidak bersifat mutlak benar seratus persen, penemuannya bersifat relatif sehingga siswa dianjurkan untuk menemukan sendiri pengetahuannya sehingga keterampilan proses sains siswa muncul dan dapat dikembangkan secara maksimal [3].

Kecenderungan pembelajaran IPA yang dialami saat ini hanya sebagai produk, dan siswa hanya menghapal teori-teorisaja [4]. Hal ini diperparah dengan adanya anggapan bahwa IPA merupakan pelajaran yang sulit sehingga menurunkan motivasi belajar peserta didik. Padahal motivasi menentukan tingkat berhasil atau gagalnya perbuatan belajar murid [5]. Dikatakan pula oleh Wina bahwa siswa akan memiliki motivasi belajar yang tinggi manakala dilibatkan langsung dalam merumuskan masalah yang dikaji [6].

Berdasarkan observasi lapangan melalui teknik wawancara dengan guru biologi yang dilakukan di MAN 1 Indramayu, diperoleh beberapa permasalahan dalam pembelajaran biologi, yakni proses pembelajaran di sekolah masih menggunakan pembelajaran konvensional, dimana pada proses pembelajaran tersebut lebih sering menggunakan metode ceramah.

Pembelajaran yang berlangsung secara konvensional identik dengan latihan soal, dan hanya dilihat nilai akhirnya, belum dinilai secara proses, sedangkan keterampilan proses sains menekankan untuk menggunakan pikiran, nalar dan perbuatan. Jika yang dinilai hanya kognitifnya saja tanpa melihat sikap dan psikomotor maka keterampilan proses sains siswa tidak diketahui, selanjutnya saat siswa melakukan praktikum, penilaian terhadap siswa tidak menggunakan indikator keterampilan proses sains. Hal ini dikarenakan untuk mengetahui keterampilan proses sains pada siswa memerlukan waktu yang lama sehingga menuntut perhatian guru, serta perencanaan yang baik sehingga guru tidak menggunakan indikator keterampilan proses sains saat praktikum berlangsung.

Faktor lain yang menghambat kegiatan praktikum Biologi baik yang menggunakan alat-alat laboratorium maupun praktikum di lapangan (observasi) jarang dilakukan karena keterbatasan alat dan bahan di laboratorium.

Keterampilan proses sains dalam pembelajaran kurang terstimulus dan terlatih, karena pengajar cenderung menekankan pada tingkat pengetahuan. Keterampilan siswa yang belum terlatih diantaranya keterampilan dalam mengobservasi, mengklasifikasikan, mengomunikasikan dan menyimpulkan. Keterampilan tersebut seharusnya sudah dikuasai namun menjadi hal yang tidak biasa dilakukan. Padalah keterampilan tersebut merupakan karakteristik dari pembelajaran IPA [7].
Berdasarkan permasalahan yang telah dikemukakan, Peneliti tertarik untuk menggunakan suatu model sebagai salah satu solusi alternatif dalam kegiatan pembelajaran yaitu dengan menggunakan model open inquiry. Alasan peneliti memilih model open inquiry karena model tersebut dapat disesuaikan dengan indikator keterampilan proses sains yang disesuaikan dengan tingkatan umur siswa dengan kesulitan yang berbeda, siswa akan mengerti konsepkonsep dan ide-ide dasar baik, membantu menggunakan ingatan kepada situasi-situasi proses belajar mengajar yang baru, mendorong siswa untuk berpikir cermat dalam merumuskan hipotesisnya sendiri sehingga siswa dapat mengidentifikasi dan merumuskan berbagai topik permasalahan yang hendak diselidiki [8].

Model open inquiry diharapkan siswa akan lebih mudah memahami materi dan dapat melatih keterampilan proses sains siswa dalam kegiatan pembelajaran Biologi di kelas. Selain itu model open inquiry dipilih karena pada setiap langkah model pembelajaran ini memberikan kesempatan kepada siswa untuk melakukan pengamatan, bertanya, mengajukan dugaan-dugaan, mengumpulkan data, melakukan percobaan, dan membuat kesimpulan. Sehingga siswa dapat belajar lebih bermakna, serta lebih antusias dalam proses pembelajaran dan mampu mengkontruksikan pengetahuan berdasarkan temuan-temuan dari proses percobaan yang telah mereka lakukan.

\section{METODE PENELITIAN}

Jenis penelitian yang digunakan adalah True Experimental Design. Dalam penelitian ini akan diberikan treatment atau perlakuan untuk kelas eksperimen dan satu kelas untuk kelas kontrol, dan mengambil data pada saat pembelajaran dan akhir pembelajaran dengan memberikan posttest pada masing-masing kelas untuk mengetahui pengaruh model open inquiry terhadap keterampilan proses sains. Sedangkan untuk desain penelitian yang digunakan adalah posttest-only control desing [9].

Populasi dalam penelitian ini adalah seluruh siswa kelas X MIA MAN I Indramayu, yang terdiri dari tujuh kelas dengan jumlah siswa sebanyak seratus delapan puluh lima. Sampel dalam penelitian ini menggunakan dua kelas, yaitu kelas X MIA 1 sebagai kelas experimen yang berjumlah 25 siswa dan kelas X MIA 2 sebagai kelas kontrol yang berjumlah 20 .

Teknik pengambilan sampel dalam penelitian ini menggunakan teknik Probability sampling. Instrumen dalam penelitian ini yaitu tes dalam bentuk soal essay atau uraian yang berjumlah 5 item.

Teknik pengumpulan data penelitian ini mengunakan tes. Tes diberikan di akhir pembelajaran pada kelas kontrol dan kelas eksperimen. Kelas eksperimen adalah kelas yang mengunakan model 
pembelajaran Open Inquiry pada pembelajarannya, sedangkan kelas kontrol adalah kelas yang menggunakan metode ceramah atau media standar sekolah setempat dengan materi yang sama yaitu materi ekosistem. Setelah selesai pembelajaran masing-masing siswa diberikan posttest dengan kriteria tes yang sama yang selanjutnya akan dianalisis hasilnya

\section{HASIL DAN PEMBAHASAN}

Penilain diberikan dalam proses pembelajaran untuk mengetahui rata-rata hasil posttest untuk mengetahui keterampilan proses sains siswa pada kelas eksperimen menggunakan model open iquiry dan kelas kontrol menggunakan model konvensional. Selain rata-rata hasil posttest dianalisis juga hasil capaian rata-rata tiap indikator keterampilan proses sains pada kelas eksperimen dan kelas control, seperti yang disajikan pada gambar berikut:

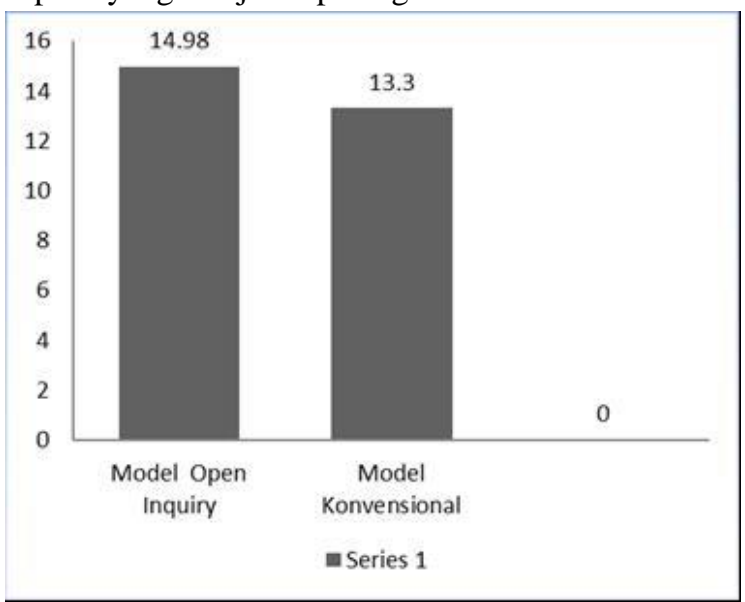

Gambar 1. Hasil Rata-rata posttest kelas yang menggunakan Model Open Inquiry dan Model Konvensional

Hasil rata-rata posttest pada kelas eksperimen yang menggunakan model open inquiry diperoleh nilai 14,98 dan kelas kontrol yang menggunakan model konvensional diperoleh nilai 13,30. Dari data tersebut maka menunjukkan terdapat perbedaan keterampilan proses sains siswa antara kelas kontrol dan kelas eksperimen. Setelah diperoleh hasil ratarata dari kedua kelas tersebut, maka didapat pula hasil keterampilan proses sains dari tiap indikator yang digambarkan dalam berikut ini:

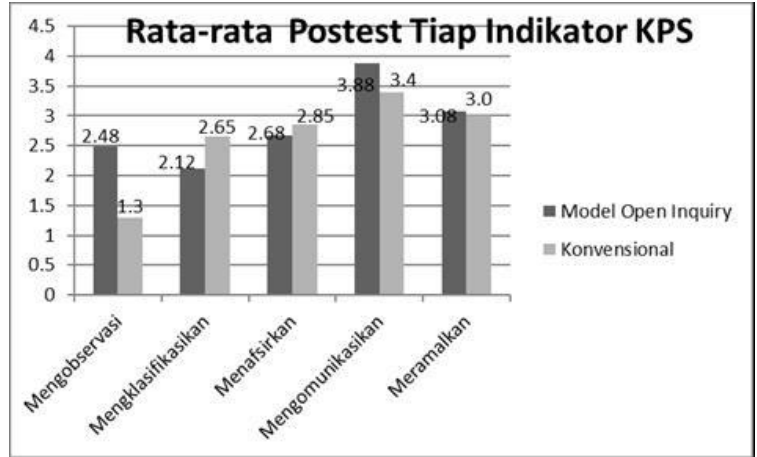

Gambar 2. Perbandingan Rata-rata Postest Setiap Indikator Keterampilan Proses Sains

Berdasarkan gambar 2 di atas, menunjukkan rata-rata posttest setiap indikator keterampilan proses sains pada kelas yang menggunakan model open inquirydan model konvensional sebagai berikut: pada indikator mengobservasi kelas yang menggunakan model open inquiry untuk indikator mengobservasi memperoleh rata-rata sebesar 2,48 indikator mengklasifikasikan 2,12, indikator menafsirkan 2,68, indikator mengomunikasikan 3,88 dan indikator meramalkan 3,08.

Sedangkan pada kelas yang menggunakan model konvensional untuk indikator mengobservasi memperoleh rata-rata sebesar 1,3, indikator mengklasifikasikan 2,65, indikator menafsirkan 2,85, indikator mengomunikasikan 3,4 dan indikator meramalkan 3,0.

Nilai rata-rata dari kedua kelas tersebut, dilakukan uji prasyarat, yaitu uji normalitas dan homogenitas baik pada kelas eksperimen maupun kelas kontrol. Pada penelitian ini diperoleh hasil uji normalitas, uji homogenitas dan uji rata-rata sebagai berikut:

Tabel 1. Uji Normalitas kelas yang menggunakan model open inquiry dan model konvensional

\begin{tabular}{|c|c|c|c|}
\hline Kelas & $\mathbf{X}^{2}$ hitung & $\mathbf{X}^{\mathbf{2}}$ tabel & Keterangan \\
\hline $\begin{array}{c}\text { Open } \\
\text { Inquiry }\end{array}$ & 1,0845 & 5,991 & Normal \\
\hline $\begin{array}{c}\text { Konvensio } \\
\text { nal }\end{array}$ & 1,7168 & 5,991 & Normal \\
\hline
\end{tabular}

Berdasarkan tabel di atas diketahui bahwa kelas yang menggunakan model open inquiry terhadap keterampilan proses sains diperoleh nilai $\mathrm{X}^{2}$ hitung $=$ 1,0845 dan $X_{\text {tabel }}^{2}=5,991$. Sedangkan pada kelas yang menggunakan model konvensional diperoleh nilai $X_{\text {hitung }}^{2}=1,7168 \mathrm{dan} X_{\text {tabel }}^{2}=5,991$. Jadi kedua data tersebut sama-sama memiliki nilai $\mathrm{X}^{2}$ hitungyang lebih kecil dibandingkan dengan nilai $\mathrm{X}_{\text {tabel }}^{2}$ sehingga kedua data tersebut berdistribusi normal. 
Tabel 2. Uji Homogenitas Kelas yang Menggunakan Model Open Inquiry dan Model Konvensional

\begin{tabular}{|l|c|c|c|c|}
\hline \multicolumn{1}{|c|}{ Kelas } & $\begin{array}{c}\text { Varian } \\
\mathrm{s}\left(\mathrm{S}^{2}\right)\end{array}$ & $\mathrm{F}_{\text {hitung }}$ & $\begin{array}{c}\mathrm{F}_{\text {tabe }} \\
\mathrm{l}\end{array}$ & $\begin{array}{c}\text { Keteranga } \\
\mathrm{n}\end{array}$ \\
\hline $\begin{array}{l}\text { Model Open } \\
\text { Inquiry }\end{array}$ & 6,43 & 1,542 & $\begin{array}{c}2,1 \\
1\end{array}$ & Homogen \\
\cline { 1 - 2 } $\begin{array}{l}\text { Model } \\
\text { Konvensiona } \\
1\end{array}$ & 4,17 & & & \\
\hline
\end{tabular}

Setelah data memenuhi persyaratan normalitas dan homogenitas, maka dilakukan pengujian hipotesis. Ringkasan perhitungan uji hipotesis kelas eksperimen dan kelas kontrol sebagai berikut:

Tabel 3. Pengujian Hipotesis

\begin{tabular}{|c|c|c|c|c|c|}
\hline Kelas & $\begin{array}{c}\text { Varians } \\
\left(\mathrm{S}^{2}\right)\end{array}$ & $\begin{array}{c}\text { Rata- } \\
\text { rata }\end{array}$ & $\mathrm{S}_{\text {gab }}$ & $\begin{array}{c}\mathrm{t}_{\text {hitun }} \\
\mathrm{g}\end{array}$ & $\mathrm{t}_{\text {tabel }}$ \\
\cline { 1 - 5 } $\begin{array}{c}\text { Model } \\
\text { Open }\end{array}$ & 6,43 & 14,98 & $\begin{array}{c}2,33 \\
05\end{array}$ & $\begin{array}{c}6,02 \\
15\end{array}$ & $\begin{array}{c}1,67 \\
1\end{array}$ \\
\cline { 1 - 2 } $\begin{array}{c}\text { Inquiry } \\
\text { Model } \\
\text { Konvens } \\
\text { ional }\end{array}$ & 4,17 & 13,20 & 05 & \\
\hline
\end{tabular}

Berdasarkan hasil analisis data, pada posttest diperoleh $t_{\text {hitung }}$ sebesar 6,0215. Sedangkan $t_{\text {tabel }}$ dengan taraf signifikan 0,05 sebesar 1,671. Karena $t_{\text {hitung }}>t_{\text {tabel }}$, maka terima $\mathrm{H}_{\mathrm{a}}$ dan tolak $\mathrm{H}_{0}$ sehingga dapat disimpulkan bahwa terdapat pengaruh keterampilan proses sains yang signifikan antara kelas yang menggunakan model open inquiry dan kelas yang menggunakan model konvensional.

Open Inquiry siswa diberi kebebasan dan inisiatif untuk memikirkan cara memecahkan persoalan yang dihadapi [10]. Inkuiri merupakan pendekatan yang mempersiapkan peserta didik pada situasi untuk melakukan eksperimen sendiri secara luas agar melihat apa yang terjadi, ingin melakukan sesuatu, mengajukan pertanyaan-pertanyaan, dan mencari jawabannya sendiri, serta menghubungkan jawaban yang satu dengan yang lain, membandingkan apa yang ditemukannya dengan yang ditemukan peserta didik yang lain. Selain itu, pada model Open Inquiry siswa diberikan kebebasan sehingga menjadi lebih aktif dalam kegiatan praktikum sehingga menghasilkan pengetahuan ilmiah dan mengembangkan keterampilan penyelidikan [11].

Berbeda dengan model konvensional yang selama ini diterapkan guru, proses belajar mengajar dilakukan dengan cara yang lama, yaitu dalam penyampaian pelajaran guru menggunakan metode ceramah, dalam proses pembelajaran penyampaikan materi tidak melakukan tahap merumuskan masalah dan membuat hipotesis, sehingga siswa belum dapat mengerti konsep-konsep dan ide-ide dasar, yang mana dapat diketahui berdasarkan pemahaman saat mendengarkan secara teliti serta mencatat penjelasan guru saat pembelajaran berlangsung. Hal ini mengakibatkan peserta bersifat pasif, karena peserta didik hanya menerima apa yang disampaikan oleh pengajar, akibatnya peserta didik mudah jenuh, kurang inisiatif, dan bergantung pada pengajar.

Model konvensional pengajar memegang peranan utama dalam menentukan isi dan urutan langkah dalam penyampaian materi kepada peserta didik. Sementara peserta didik mendengarkan secara teliti serta mencatat pokok-pokok penting yang dikemukakan guru [12]. Adanya perbedaan kemampuan akhir antara kelas eksperimen dan kelas kontrol namun perbedaannya tidak terlalu jauh atau signifikan. Karena beberapa faktor, diantaranyafaktor ketidaknyamanan siswa. Dimana ketidaknyamanan siswa merasa asing terhadap model pembelajaran, siswa yang lebih sering menggunakan model konvensional sehingga saat pembelajaran berlangsung menggunakan model open inquiry pelaksanaan kurang optimal [13].

Adanya perbedaan skor rata-rata siswa yang diperoleh siswa pada kelas yang menggunakan model open inquiry dan kelas yang menggunakan model konvensional karena pada model pembelajaran ini dapat diaplikasikan pada setiap umur dengan kesulitan yang disesuaikan dengan tingkat pendidikan yang ada, selain itu dengan merumuskan masalah akan menstimulus siswa dalam menemukan konsep dan ide yang dapat menjawab rumusan masalah yang telah dibuat sehingga siswa merasa termotivasi dan menimbulkan dugaan-dugaan sementara atau biasa disebut dengan hipotesis, akhirnya siswa memiliki pemahaman materi yang lebih baik dibandingkan kelas yang menggunakan model konvensional. Strategi inkuiri berarti suatu rangkaian kegiatan belajar yang melibatkan secara maksimal seluruh kemampuan siswa untuk mencari dan menyelidiki secara sistematis, kritis, logis, analitis, sehingga mereka dapatmerumuskan sendiri penemuannya dengan penuh percaya diri [14].

\section{KESIMPULAN}

Berdasarkan hasil penelitian dan analisis data yang telah dilakukan maka dapat disimpulkan bahwa model open inquiry efektif terhadap keterampilan proses sains siswa pada materi ekosistem.

\section{DAFTAR PUSTAKA}

[1] Hadisaputra, S., Ihsan, M. S., \& Ramdani, A. (2020). The development of chemistry learning devices based blended learning model to 
promote students' critical thinking skills. JPhCS, 1521(4), 042083

[2] Kemendikbud. 2014. Materi Pelatihan Guru Implementasi Kurikulum 2013. Tahun Ajaran 2014/2015 Mata Pelajaran Biologi SMA/SMK. Jakarta: Badan Pengembangan SDM Pendidikan dan Kebudayaan dan Penjaminan Mutu Pendidikan.

[3] Conny Semiawan. 1992. Pendekatan Keterampilan Proses Bagaimana Mengaktifkan Siswa Dalam Belajar. Jakarta: Grasindo.

[4] Trianto. 2010. Model-model Pembelajaran Inovatif Berorientasi Konstruktivistik. Jakarta: Prestasi Pustaka.

[5] Oemar Hamalik. 2007. Proses Belajar Mengajar. Bandung: Bumi Aksara.

[6] Wina Sanjaya, 2006. Strategi Pembelajaran Berorientasi Standar Proses Pendidikan. Jakarta: Kencana.

[7] Lissa. (2018). Penggunaan Media Kunci Determinasi Terhadap Keterampilam Proses Sains Siswa Pada Materi Hewan di SMA Negeri 1 Sindang. Jurnal Mangifera Edu. 2 (2). 71-77.

[8] Taringan, Simeon 2013. Implementasi Pendekatan Inkuiri Dalam Pendidikan IPA. Bandung: PT. Remaja Rosdakarya.

[9] Sugiyono. 2018. Metode Penelitian Pendidikan. Bandung: Alfabeta.

[10] Suryani D.I dan Sudargol.F, (2015). Pengaruh Model Pembelajaran Open Inquiry dan Guided Inquiry Terhadap Penguasaan Konsep Siswa SMP pada Tema Suhu dan Perubahan. Jurnal Edusains. 7(2). 127-134.

[11] Mulyasa. 2013. Menjadi Guru Professional. Bandung: PT Remaja Rosdakarya.

[12] Jainuri, M. 2015. Pembelajaran konvensional, [Online] Tersedia: https://www.academia.edu.

[13] Ramayanti, Indra dan Lilis. L. (2019) Pengaruh Model Free Inquiry terhadap Keterampilan Proses Sains. Jurnal Quagga 11 (1). 20-26

[14] Trianto. 2012. Model Pembelajaran Terpadu. Jakarta: Bumi Aksara 